\title{
Adenovirus Encoding Rat HER-2/neu
}

National Cancer Institute

\section{Source}

National Cancer Institute. Adenovirus Encoding Rat HER-2/neu. NCI Thesaurus. Code C62527.

A replication-defective oncolytic adenovirus, encoding rat Her-2/neu (ErbB-2), with potential antineoplastic activity. Upon administration, adenovirus encoding rat HER-2/neu may induce an immune response against tumor cells expressing the HER-2/neu antigen, which may result in the immune-mediated inhibition of tumor cell proliferation and tumor cell death. Her-2/neu, a tumor-associated antigen and member of the epidermal growth factor receptor (EGFR) family of tyrosine kinases, is overexpressed in various tumor cell types. 